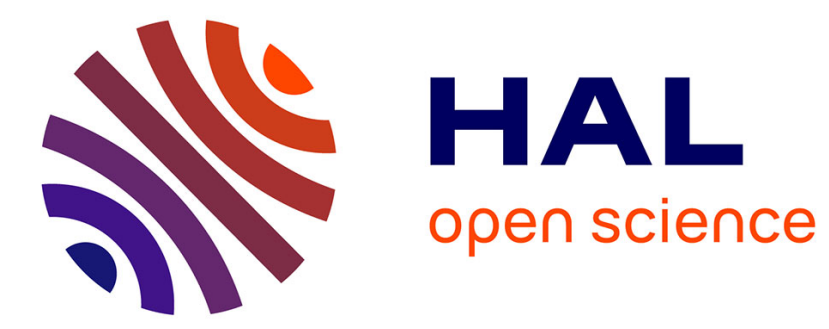

\title{
Unravelling identities
}

Zahbia Yousuf

\section{To cite this version:}

Zahbia Yousuf. Unravelling identities. European Journal of Cultural Studies, 2007, 10 (3), pp.360-373.

10.1177/1367549407079709. hal-00571549

\section{HAL Id: hal-00571549 \\ https://hal.science/hal-00571549}

Submitted on 1 Mar 2011

HAL is a multi-disciplinary open access archive for the deposit and dissemination of scientific research documents, whether they are published or not. The documents may come from teaching and research institutions in France or abroad, or from public or private research centers.
L'archive ouverte pluridisciplinaire HAL, est destinée au dépôt et à la diffusion de documents scientifiques de niveau recherche, publiés ou non, émanant des établissements d'enseignement et de recherche français ou étrangers, des laboratoires publics ou privés. 


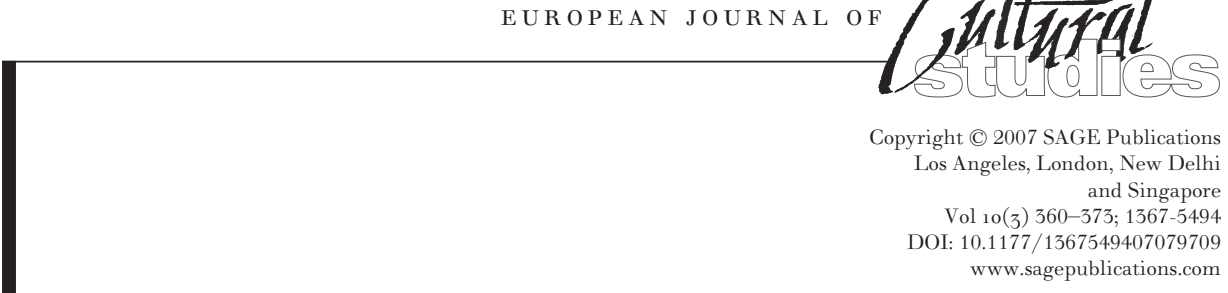

\section{Unravelling identities \\ Citizenship and legitimacy \\ in a multicultural Britain}

\section{Zahbia Yousuf}

King's College London

ABSTRACT The decision to go to war by the government of the day is assumed to be a decision taken on behalf of all citizens of the nation, conceived as a collective united by a harmony of interests. Yet in the case of the Iraq

War, there is clearly no unified voice of support from the British people. There is division between the state and its citizens, and the latter also reflect the multilayered identities of an increasingly multicultural society. How do individuals displaying multilayered identities relate politically, socially and culturally to the abstract, unified idea of Britishness, and how does this impact upon perceptions concerning the legitimacy of state action?

KEYWORDs Britishness, citizenship, identity, Iraq War, legitimacy, media, multiculturalism, nation-state, security

\section{Introduction}

This article examines the political and social space of a multicultural state. It is based on interviews with multicultural news audiences in Northern Ireland and London: Indian households, including those of both Hindu and Muslim religious backgrounds. Five households, altogether comprising 10 respondents, were selected to ensure variation in age, class, gender, religious belief, group size, length of time living in Britain and diasporic generation: two married couples, one household of two parents and an adult son, two house sharers, and one adult living alone. Table 1 (appended) sets out the respondents' demographics. The study of each household's engagement with news resources was carried out through a series of 60-90-minute, semi-structured interviews, using images from various media sources, over a period of 11 months (April 2005 to February 2006). Based on these interviews, this study will consider whether and how multilayered identities (based on ethnicity, social class, religious beliefs and gender) influence and are influenced by news consumption, and how this has an impact on issues of security within the multicultural space of the nation. 
The respondents' historical context was dominated by the 'War on Terror' and the war in Iraq. The decision to go to war in Iraq in 2003 was divisive the world over. Within the UK, the government appeared to defy an immense tide of popular anger and resistance. The citizens of the country had spoken but had gone unheard, and as a result many felt disenfranchised. But a central goal of the modern state is to persuade its subjects to support and sanction the costs of its policies. Ideally, the population unites behind the state, sharing a unified collective mind. However, as the Iraq War proves, an increasingly multicultural society challenges the traditional, cultural concept of the nation. What is the impact on the idea of a 'unified collective mind of the population' when individuals and groups assert multilayered identities rather than a singular national one? Questions about the relationship between the citizen and state, including notions of citizenship, loyalty to the state and perceptions of the legitimacy of state action become pertinent here. If political loyalty is traditionally expected to come from a unified, homogeneous nation, is this threatened by loyalties of a communal kind, such as ethnic, religious and regional loyalties, whether local or transnational (Delanty, 2003)? Should or can a multicultural society focus the multilayered loyalties of citizens onto a single identity based around a harmony of interests - that is, create a congruent civic identity?

This article explores the relationship between multilayered identities and the state in relation to an abstract idea of a British national identity ('Britishness') that suggests uniformity. Is there space within such an idea of Britishness to assert cultural differences and, if so, how do people choose to do so? How do such differences impact on the idea of a shared civic and political identity and on the balance between cultural, religious and social affinities and civic identity? How are security concerns influenced by, and how do they influence, notions of identity in Britain? How, if at all, do citizens distinguish between loyalty to the government and the idea of the nation?

\section{Theoretical background}

The idea of the 'nation' has been understood as an ideological construct essential to assigning subject positions in the modern state (Hobsbawn and Kertzer, 1992). The cultural image of the nation is based around a shared sense or sentiment of belonging together; a nation comprises all those of supposedly common language history or broader cultural identity (Habermas, 1992). The assumption is that the demos of citizens must be rooted in the ethnos of nationals if a stable society is to be achieved. The 'binding force of citizenship' is thought to be insufficient to generate loyalty unless anchored in a prior, shared cultural community. This cultural conception of the nation implies that loyalty must be exclusive and singular; plural or shared loyalties are viewed as threats to national unity (Betts, 2002). 
However, this conception of the nation-state has been challenged by the idea of multi-ethnic societies. Contemporary cultural production facilitates the formation of multiple, especially transnational, identities; growing numbers of people have dual or multiple loyalties (Delanty, 1996). People can access multilingual, multinational newspapers online, keep abreast of news broadcasts and political, social and cultural programmes from all over the world through satellite television, and engage actively in current debate worldwide through internet weblog ('blog') sites, chatrooms and instant email. Globalization of communications allows people to align themselves with any social, cultural or political group anywhere in the world. Media culture (radio, television, film and other products) provides materials out of which we forge our very identities, sense of selfhood, notions of what it means to be male or female, sense of class, ethnicity and 'race', nationality, sexuality, and of 'us' and 'them', as Douglas Kellner (1995) argues. The ability to transcend national borders and expand democracy in the information sphere has allowed us to align ourselves more clearly with linguistic, ethnic, cultural and religious identities that extend beyond national borders.

Embracing multiculturalism creates an antagonistic relationship with traditional notions of monolithic 'national' or 'state' identities, and results in competing loyalties. Scenes such as the protests against Salman Rushdie's book The Satanic Verses (1988; see Asad, 1990), second-generation youths waving Indian and Pakistani flags at cricket matches in the north of England, and the recent row over cartoons depicting the Prophet Muhammad, in which protesters in London displayed banners glorifying terrorism and Osama bin Laden, all raise questions about the apparent paradoxes of living in a society of fractured loyalties. The revelation that British Muslims became suicide bombers in Israel and then, on 7 July 2005, in their own country, has given greater urgency to questions of loyalty.

Policy discussions have switched from embracing differences in a laissez faire multicultural society to attempting to create a strong sense of unifying 'Britishness'. In the aftermath of 7 July, the shadow Home Secretary David Davis criticized the government's multiculturalism as 'outdated': 'People from different cultures should integrate more.' The government must 'build a single nation' and demand 'respect for the British way of life' (BBC News Online, 2005). Recent think-tank publications focus on the idea of Britishness (Demos, 2006; Leonard, 2005). Gordon Brown emphasizes that "it is shared values - not colour, nor unchanging and unchangeable institutions - that define what it means to be British in the modern world'. With this definition, he argues,

we can be far more ambitious in defining for our time the responsibilities of citizenship; far more ambitious in forging a new and contemporary settlement of the relationship between state, community and individual; and it is also easier too to address difficult issues that sometimes come under the heading 
differences, can find the essential common purpose without which no society can flourish. (Brown, 2005)

Defining Britishness as a civic identity rather than a cultural one implies that there is no inherent difficulty in being, for example, both British and Muslim. However, as argued by the Parekh Report on the future of multiethnic Britain (Runnymede Trust, 2000), Britain is not only a territorial and political entity, but also an 'imagined community' (Anderson, 2000). Regardless of the inequalities that prevail, every nation is conceived as a deep, horizontal comradeship, a psychologically-represented social system. From this perspective, as the Parekh Report identified, the fundamental questions are: what is Britain's understanding of itself? How can everyone find recognition and develop a sense of belonging in Britain? Do people believe that it is important to share a common British value system? In response to the Parekh Report, Anne-Marie Fortier considers that the vision of British tolerance and 'rich mix' offers freedom, movement and choice to British citizens (Fortier, 2005). This vision allows - indeed prescribes - a detachment from some ethnic identifications and differences in favour of an attachment to an idealized, abstract, post-ethnic British citizen. Thus, since 11 September 2001, British Muslims have frequently been called upon in the media to show their allegiance to Britain by condemning attacks and supporting military action in Afghanistan and Iraq, thus legitimizing the British position. In particular, Iraqi immigrants or exiles were called upon to speak up in support of this 'moral war' (Fortier, 2005).

Traditionally, war has been seen to bring citizens of a nation closer together, greatly reinforcing the sense of national belonging (Rex, 1996). Attempts to create a culturally neutral British identity based on the idea of political citizenship assume a utopian abstraction of the nation; in this imagined community of shared allegiance, 'differences' are transcended at the level of action. To belong to a polity means to identify with, and be loyal to, the key legal and political institutions and principles that guarantee the political life of the society (Mason, 1999). Rather than through a traditional, cultural concept of nation, bonds are created through shared civic and political values. Traditionally, loyalty largely operated outside the political culture of democracy, based on cultural affinities to a nation. Today, loyalty is entering increasingly into the language of politics, while loyalties are increasingly conditional (Delanty, 2003). They are intertwined with ideas of a well-functioning democracy and cannot be derived from uncritical values of duty, patriotism or obedience. Citizens' assessment of the legitimacy of the state and of government action impacts on their notions of loyalty. Loyalties can be recalcitrant and unpredictable, and this is especially the case where political élites are perceived as having betrayed democracy.

\section{Analysis}

The analysis focuses on four themes: media consumption and impressions of media credibility; security concerns; sense of identity; and the state, 
democracy and legitimacy. All respondents' names have been changed to protect their anonymity.

\section{Media consumption and impressions of media credibility}

The media we choose to engage with, and how we interpret them, reflect how we choose to identify ourselves socially, culturally and politically. The respondents attached different assumptions to news sources regarding credibility and bias. They responded quite strongly in favour of the BBC, despite recent criticism of BBC coverage, particularly since the beginning of the Iraq War. The BBC was generally regarded as distinctly British and considered to be synonymous with credibility and legitimacy. For second-generation respondents it reflected a continuation of their parents' choice: 'what they had always watched'. It was the main news source for all respondents.

The availability of other sources provided an outlet and stimulation for various linguistic and cultural attachments. First-generation immigrants Fauzia and Jameel, Maya and Deepak watched South Asian-language channels (Zee TV, Vectone) mainly for entertainment rather than news. Deepak and Maya watched Star News in order to keep abreast of current news in India, and read The Hindustan Times and The Hindu online. Fauzia and Jameel on the other hand gave priority to current affairs on British news channels: 'Although we have come from India, we are not so in touch with the politics in India so much.' There was also a credibility issue. Both these sets of respondents commented that Indian-based news did not provide adequate coverage of international events. Deepak believed that the BBC provided better coverage than Indian channels of the IndianPakistan talks, as well as of the Iraq War.

Naseem, Karim, Fauzia and Jameel also found it useful to engage with news from a Muslim perspective through satellite television and the internet. They watched the Islam Channel to obtain a critical perspective on the BBC and took an interest in the Islam Channel discussion forums about Muslims in Britain. Fauzia and Jameel also read Al-Jazeera online for news relating to the Muslim world.

The western media relies on Al-Jazeera for news sources. They tend to be held in high esteem, so I would rely on Al-Jazeera, but I don't think that I would rely too much on Muslim newspapers or Muslim media here, though I would believe them but not to that extent. I would tend to rely more on the national media here, like [the] BBC. (Jameel)

Global insecurity featured very much in the responses. There was a clear preoccupation with global events, particularly with the Iraq War, the 'War on Terror' and Palestine. Most respondents showed a much greater interest in global foreign affairs than local or national issues. Interest in security-salient issues was not directly linked to the respondents' own perceptions of insecurity, which were of a local nature. Jameel and Fauzia, and Naseem and Karim, had a longstanding interest in issues concerning 
Muslims worldwide. All framed their responses with reflections on how Muslims were represented in the media.

Credibility of news was extremely important for all the respondents and was the main criteria used in their choice of news source. Credibility is a subjective measure, linked with how the respondents aligned themselves politically, socially and culturally, but chiefly to the range of issues covered. The BBC and the Guardian scored highly because of their worldwide coverage and perceived factual approach. Stations such as Sky and CNN, and publications such as the Mirror and the Sun, were criticized as 'sensationalist' and 'tabloidy'. Referring to headlines in the Mirror after the 7 July bombings, Naseem commented: 'That is not what we have come to expect from the British media.' The respondents generally expressed high expectations of the media in Britain, considering the investigative journalism to be fairly unbiased. Reference was made specifically to the BBC (including Newsnight), the Guardian, Independent and The Times. All the respondents made comparisons with the news culture in the US, where news channels, specifically CNN and Fox, were seen to reflect a biased and narrow news culture. However, Naseem and Karim perceived bias against the Muslim world in the BBC too:

That newswoman on the BBC, what's her name ... Orla Guerin. She is very pro-Israeli. She presents the facts but her intonation and the way she tells the facts, it sort of colours her voice.

There appears to be a slight spin on news relating to Muslims or Asians. There would be the odd word thrown in: 'A gang of four boys did this.' Well, that becomes: 'A gang of four Asian boys did this.' Maybe we are just sensitive to it. Maybe nobody else sees it that way, but we can see that in many stories. (Karim)

Naseem expressed frustration: 'That it is not portraying Islam in a very fair light.' She also highlighted the compelling nature of the media:

It is especially frustrating because it is almost like being mesmerized by it, so you have to watch it. You know even before you sit down to watch it that it is going to be biased. And it's going to be biased in a negative light [against Muslims]. But still you have to watch it.

\section{Security concerns}

'Political insecurity worldwide', as Zain put it, was a major topic of concern. Deepak thought that the British Government should be paying more attention to Palestine. Deepak, Jameel, Naseem and Karim took a critical stance on Britain's role in Iraq, displaying a greater empathy for the Iraqi people than concern for British troops. During discussions about the Abu Ghraib prisons, much empathy was shown for the prisoners by Jameel, Fauzia, Maya and Naseem. This empathy arose more from human compassion than from any political or religious identification:

I can't believe that people can act that way towards another human being. It's disgusting. There is no sense of respect for other human beings there. (Maya) 
These [soldiers] are in a role of responsibility towards these prisoners. They have no right to act like that towards any human being, but especially when they have this duty. (Jameel)

Terrorism featured prominently in the discussions. All the respondents viewed the risk as being exaggerated by the government (that is, the British Government) and the media. The term 'War on Terror' was seen as government rhetoric and its use as contemptibly heightening public fears. Before the London bombings of 7 July 2005, none of the respondents thought that there was a credible threat to Britain from terrorism. The bombings did not augment any sense of a threat from terrorism. Despite respondents' earlier dismissal of such a threat, there was little surprise that this had actually occurred. Arjun, for example, claimed:

It wasn't a shock. When someone told me I was like, 'Oh.' It was expected,

I suppose. London was expecting an attack at some point.

For those living in London there was only a short-term fear that

after the [attempted] second bombing [on July 21] that this would be happening every Thursday. (Arjun)

For Muslim respondents, the main security concern after the bombings was the fear of a backlash against the Muslim community:

Not just throwing bricks at mosques, burning down buildings but also a complete mistrust of the Islamic community, almost a mutual distrust from both sides. (Saima)

This concern was not tied to a sense of immediate threat to personal safety. Jameel, in Northern Ireland, stated that there was no increased cause for concern locally, yet he felt threatened all the same. There was a general sense of Muslims being mistrusted within British society:

In our own selves we felt quite threatened because this thing has happened and we should be prepared for a backlash, the immediate backlash and the long-term, slow build-up of backlash against Muslims. I'm more afraid not of the immediate backlash, but concerned about long-term backlash, something growing on and on, which never dies in people's mind. (Jameel)

The issue of balancing civil liberties against security also arose. A sense of mistrust in the government, particularly in Tony Blair, reduced support for legislation introduced to deal with heightened security risks from terrorism. There was acceptance of some new security measures as necessary, but there was concern that these could lead to prejudice against certain minorities:

It automatically assumes that all Muslims, or all Asian Muslims, because there are a lot of Muslims that don't look like Muslims ... Those with coloured skin find that there is a huge prejudice [against them], that because of the colour of my skin and because I am wearing a headscarf, I have terrorist tendencies. (Naseem) 


\section{Sense of identity}

The identities asserted by the respondents were influenced by factors such as ethnicity, religion, national ties and length of residence in Britain. First-generation immigrants Jameel, Fauzia, Deepak and Maya asserted a closer attachment to an Indian identity than second-generation immigrants, primarily evidenced through subscriptions to satellite channels from the subcontinent. Jameel and Fauzia expressed more of a cultural link with India, viewing these channels for mainly entertainment purposes and expressing a strong sense of civic responsibility within Britain with respect to voting in elections and abiding by the law. Deepak and Maya's greater interest in Indian politics was also balanced by a strong civic responsibility with regard to Britain. Arjun, a second-generation, non-practising Hindu, expressed no identity other than British. In response to questions about the 7 July bombers, his analysis was based on loyalty and citizenship: he condemned the bombers' disloyalty to a country where they had enjoyed the benefits of education and citizenship.

Most Muslim respondents, first- and second generation, expressed a clear pan-Islamic identity as the basis for their framework of interpreting news information and public policy. When asked to consider many newspaper photographs from the 7 July bombings and to select the one which best summed up the event, Jameel selected a picture of a Muslim looking through a pane of a broken glass: he said it reflected his fears of a backlash against the Muslim community. Even to Zain, not a practising Muslim:

There is a general feeling around the world amongst the Muslim communities of 'them and us', that the Muslim community is being victimized throughout the world.

The strength of a pan-Islamic identity was expressed through concern for events in Muslim countries (e.g. Iraq, Afghanistan and Palestine) as well for the future of Muslim relations within Britain. Especially after 7 July:

It felt like Muslims kept on having to defend themselves and apologise in some way. Everywhere there were Muslim clerics saying that they didn't support terrorism; outside my local mosque there was a big banner saying 'Against Terrorism'. It felt like they had to come out and say these things so as to be acceptable, like, profess their loyalty to Britain and being British. (Saima)

The Muslim respondents felt little conflict in personally identifying themselves as both Muslim and British, but felt that the London bombings had sharply focused British society's attention on any such conflict. An occasional discourse of 'them' and 'us' seemed to reflect a sense of the Muslim community as becoming isolated from general British society, rather than a sense of segregation. This was reflected in disbelief regarding the July bombers. Jameel asked:

Were [the bombers] really British or ... recent immigrants who came and had just set up in this country? It was difficult to believe people who were born here, educated here, could do that. 
Jameel and Osman admitted that, living in Northern Ireland, they held similar stereotypes of Muslims in England to those that the media and the British public held. Osman described moving to London from Northern Ireland:

Coming from Northern Ireland, my exposure to Muslims was very different from what you get in inner-city London. I found 19-, 20-year-olds with fistlength beards wearing traditional eastern dress, the stereotypes that people associate with Muslims and terrorism and extremism. I would have shared some similar views to the extent that if there are people like this, they are probably the ones who carry out things like this. So the eye-opener was seeing boys running around in western dress, who didn't have massive beards or massively over-Islamic overtones. Just normal Muslim kids, you couldn't tell ... I thought I could tell which direction they were coming from, but now I don't know. (Osman)

Arjun showed similar surprise that

a lot of these guys [the bombers] were everyday school kids, 18-, 19-year-olds. So it could be anyone, not necessarily the guy that looks really dodgy in the corner with the big beard or the long hair, holding the Koran.

Although Arjun and Deepak questioned the bombers' loyalty, they were not surprised that they had been British. Arjun had heard of similar people going to be suicide bombers in Palestine, and Deepak knew of comparable incidents in India.

All held civic responsibility to be an important value of British society. It was this which gave rise to a sense of loyalty to the country, a loyalty which the bombers had clearly violated. The respondents believed strongly in the idea of a multicultural society. For them, this entailed citizens not simply abiding by the laws of the land, but integrating, in the sense of developing civic ties and responsibilities, and respecting principles of democracy. These questions also arose in discussions of the cartoons depicting the Prophet Muhammad. For the Muslim respondents, the issue created conflict between loyalty to religious principles and recognition of the importance of freedom of speech. Jameel tried to reconcile free speech with Islamic principles forbidding the depiction of the Prophet, by limiting free speech where it was insulting and degrading:

As Muslims we believe that the Prophet should not be depicted. However, in name of free speech you can draw a cartoon or a figure, but that is not as bad as what been presented here: this is to ridicule and insult someone who[m] a community holds sacred. Freedom of speech should not mean insult or incite hatred. (Jameel)

Jameel, like Arjun and Osman, stressed education as a means of discouraging extremist elements and promoting integration within a multicultural society. 


\section{The state, democracy and legitimacy}

The discussions covered the ideas of a democratic state and government, the legitimacy of state action and individuals' sense of trust towards the government. Tolerance, equality and democracy were terms frequently associated with British society. Deepak expressed a strong feeling of respect for the traditional democratic structures of Britain in comparison to those in India, and both Deepak and Jameel emphasized the importance of participating in democratic processes such as elections. The secondgeneration respondents were more apathetic towards participation in electoral processes, although they stressed that British society was based on principles of equality and tolerance. Osman and Saima particularly praised the sense of stoicism and resolve displayed by London in the wake of the July bombings, and Arjun expressed how Londoners 'just got on with everyday life', compared with the Americans and Spanish after similar attacks.

There was a general mistrust of the government. Disappointment in current politics was affirmed by Osman: Tony Blair had betrayed the Muslim community, he said, after he 'had done so much for them previously'. The Iraq War was a turning point for many, destroying trust in the government. Naseem and Karim expressed great discontent with the Blair government: now reluctant to vote; they felt disenfranchised from democratic processes. Thus the importance attached by the respondents to civic responsibility and democratic process within the state has to be considered alongside people's views of the government of the day, and the substantive nature of politics within society. Jameel and Deepak were very critical of government action over the war in Iraq, the 'dodgy dossier' concerning weapons of mass destruction and policy towards the Middle East. Distance from government policy was reflected in the use of 'they' when referring to actions such as going to war. Thus there was a clear distinction between political and civic attachment to the country and the legitimacy of government action. However, it is interesting to note that mistrust of the government arose only in matters of foreign policy. Jameel and Deepak stated that the government's domestic record was much more favourable and that it was this, rather than foreign policy, that would influence their voting behaviour.

Many of the respondents contrasted the government's rhetoric and arguments conforming to the ideals of British society, justifying the war in terms of notions of human rights, justice and democracy, with the actual behaviour of the government. The first-generation respondents showed particular indignation at this, since they had most readily identified Britain with notions of democracy and egalitarianism. Jameel and Fauzia expressed disappointment with the British Army after revelations of prisoner abuse in Iraq: 'We really didn't expect that from the British Army.' Perceived hypocrisy led to greater opposition to the war. But there was 
little hope that public outrage at the photos of prisoner abuse would be able to effect political change:

You can't do anything more about it. There have been demonstrations in this country. Generally people have become lethargic, they don't want to keep thinking about whether it was right going to war. Also, every time this issue has come up it has been covered up by the government in the last couple [of] years. (Jameel)

Others were less surprised by the actions of the British Army:

They have done it in the past, the Japanese Army, the British Army, and other armies as well. If you remember a bit of history it is not surprising or disappointing. You know that it is on the horizon once the war takes place. They talk about human rights and democracy, but at the end of the day, they are going to mistreat the people. (Deepak)

There was not much sympathy for British soldiers killed or captured: here Jameel uses a pronoun which distinguishes 'us' from majority national opinion:

It didn't create any bad feeling amongst us because it was a war. They went for war, and they should have been prepared to be captured or killed, and there were prisoners of war on both sides.

\section{Conclusion}

The instinct to forge and maintain bonds can be divisive. Multilayered cultural identities must be reconciled with an encompassing national identity. British laissez faire multiculturalism, with little insistence on minimal attachment to common values, is now widely disdained by policymakers (Lloyd, 2006). David Blunkett's introduction of citizenship tests is testament to this new thinking. This article asked how individuals displaying multilayered identities relate politically, socially and culturally to a singular idea of Britishness. The respondents clearly identified what British society represents for them in political terms: a commitment to principles of human rights, democracy, freedom of speech, tolerance and equality. These values, held in high regard, created a strong sense of civic identity. For many, active participation in electoral processes was the clearest manifestation of identification with Britain as a nation. The principles of British society and its diversity were considered to be represented by the BBC, unanimously the preferred news source. Thus the respondents attached principles of civic responsibility and democratic entitlements to the notion of Britishness rather than cultural associations such as language, ethnicity, or religion. Citizenship represents an identification with key legal and political institutions. It relates to the idea that the collective sovereignty of the state is based in common political participation. This generates a shared sense of belonging that creates a common purpose and social cohesion. 
However, this political identity and commitment to principles of civic responsibility did not translate into allegiance for the government of the day. There was widespread criticism of the government, chiefly with regard to foreign policy in the Middle East and the so-called 'War on Terror'. Actions by the state were tested against the principles that respondents had come to identify most strongly with British society. The British Army suffered the same critique when its treatment of Iraqi prisoners was scrutinized. The respondents displayed a sense of betrayal and disillusionment that the principles they associated with British society were being neglected by its institutions. This disillusionment with institutions perceived as 'British' was also reflected in the search for alternative news sources that better addressed their salient security concerns, notably channels dealing with the issues facing Muslims living in Britain.

Several strands of cultural identity were revealed. Only first-generation respondents identified readily with being Indian. Having been away from India for a longer period of time, Jameel and Fauzia expressed less political attachment and instead a continued cultural association. The strongest alternative expression of identity to being British came from the Muslim respondents, and this shaped their critique of the media, their security concerns and their attitude to the legitimacy of the government. But this assertion of Muslim identity did not conflict with the previously identified civic identity. Where there was room for conflict, the respondents' reasoning also clearly reflected a wish to reconcile differences between British values and Islamic principles, as can be seen in Jameel's reflection on the cartoons of the Prophet. The respondents felt that to criticize political institutions reflected the principles of a flourishing democratic society, without compromising their civic loyalties. However, there was a sense that the London bombings had threatened the idea of a multicultural society where multilayered identities could be expressed freely, and a feeling that the ability of Muslims to assert their religious identity was threatened. The respondents expressed concern for the future of relations between Muslims and non-Muslims within Britain and, as Saima reflected, concern that the Muslim community had to 'constantly prove its loyalty by apologizing'.

The recent emphasis on the need to unite citizens under an umbrella of Britishness is overstated. The respondents felt no conflict between being British and asserting other ethnic, cultural, linguistic or religious backgrounds. Rather than demanding an all-encompassing, unitary identity where a harmony of interests dominates, breaking down the idea of a nation creates space for the assertion of multilayered identities. The uniting principle, the basis for a democratic society, is the sense of civic identity where the individual can participate fully in democratic processes and share civic ties. The values attributed to British society are associated with political entitlements and principles of civic responsibility, to which the respondents subscribed and which they supported. The right to criticize and challenge the actions of government sustains the legitimacy of 
the state. Where they felt that these very principles were not being adhered to by political institutions, they begin to feel disenfranchised from political processes and marginalized in society. A loss in the perceived legitimacy of the government has resulted in tension with the norms of democracy on which political identity is based. Where political identity fractures, cultural identities fill the void.

\section{References}

Anderson, B. (2000) Imagined Communities: Reflections on the Origin and Spread of Nationalism. New York: Verso.

Asad, T. (1990) 'Multiculturalism and British Identity in the Wake of the Rushdie Affair', Politics and Society 18(4): 455-80.

BBC News Online (2005), 'How Multicultural is Britain?', 9 August. [Accessed 13 February 2006: http://news.BBC.co.uk/1/hi/talking_point/4741753.stm]

Betts, K. (2002) 'Democracy and Dual Citizenship', People and Place 10(1): $57-70$.

Blackhurst, R. (2004) 'A New Force in British Politics', New Statesman (26 July): 10.

Brown, G. (2005) 'On Britishness', keynote address to the Fabian New Year Conference, London, 14 January. [Accessed 30 March 2006: http://www. fabian-society.org.uk/press_office/display.asp?cat $=43 \& i d=520]$

Delanty, G. (1996) 'Beyond the Nation-State: National Identity and Citizenship in a Multicultural Society', Sociological Research Online 1(3). [Accessed 22 November 2005: http://www.socresonline.org.uk/ socresonline/1/3/1.html]

Delanty, G. (2003) 'Loyalty and the European Union', in M. Waller and A. Linklater (eds) Loyalty and the Postnational State, pp. 123-36. London: Routledge.

Demos (2006) 'Abandon Multiculturalism to Foster "Britishness", press release. [Accessed 30 March 2006: http://www.demos.co.uk/media/ pressreleases/multipleidentitiesrelease]

Fortier, A.M. (2005) 'Pride Politics and Multiculturalist Citizenship', Ethnic and Racial Studies 28(3): 559-78.

Habermas, J. (1992) 'Citizenship and National Identity: Some Reflections on the Future of Europe', Praxis International 12(1):1-19.

Hobsbawn, E.J. and D.J. Kertzer (1992) 'Ethnicity and Nationalism in Europe Today', Anthropology Today 8(1): 3-8.

Kellner, D. (1995) Media Culture. Cultural Studies, Identity, and Politics between the Modern and the Postmodern. London: Routledge.

Leonard, M. (2005) Fabian Review: The Britishness Issue (20 Dec.).

Lloyd, J. (2006) 'Hope and Glory', Financial Times Magazine (15 Jan.). [Accessed 10 February 2006: http://search.ft.com/ftArticle?queryText=Hop $\mathrm{e}+$ and + glory\&aje $=$ true\&id $=060113006247]$

Mason, A. (1999) 'Political Community, Liberal Nationalism and the Ethics of Assimilation', Ethics 109(2): 261-87.

Rex, J. (1996) 'National Identity in the Democratic Multi-Cultural State', Sociological Research Online 1(2). [Accessed 19 November 2005: http:// www.socresonline.org.uk/1/2/1.html] 
Runnymede Trust (2000) The Future of Multi-Ethnic Britain: The Parekh

Report. London: Profile.

Rushdie, S. (1988) The Satanic Verses. London: Viking.

\section{Appendix}

Table 1 Overview of interviewees

\begin{tabular}{|c|c|c|c|c|c|c|c|}
\hline Name & $\begin{array}{l}\text { Current } \\
\text { residence }\end{array}$ & Sex & Age & Employment & $\begin{array}{l}\text { Place of } \\
\text { birth }\end{array}$ & Religion & $\begin{array}{l}\text { Years in } \\
\text { current } \\
\text { residence }\end{array}$ \\
\hline $\begin{array}{l}\text { Fauzia } \\
\text { Osman } \\
\text { Jameel }\end{array}$ & $\begin{array}{l}\text { Northern } \\
\text { Ireland }\end{array}$ & $\begin{array}{l}F \\
M \\
M\end{array}$ & $\begin{array}{l}55 \\
57 \\
19\end{array}$ & $\begin{array}{l}\text { Housewife } \\
\text { GP } \\
\text { Student }\end{array}$ & $\begin{array}{l}\text { India } \\
\text { India } \\
\text { Belfast }\end{array}$ & $\begin{array}{l}\text { Muslim (P) } \\
\text { Muslim (P) } \\
\text { Muslim (P) }\end{array}$ & $\begin{array}{l}30 \\
19 \\
30\end{array}$ \\
\hline $\begin{array}{l}\text { Maya } \\
\text { Deepak }\end{array}$ & $\begin{array}{l}\text { Northern } \\
\text { Ireland }\end{array}$ & $\begin{array}{l}\mathrm{F} \\
\mathrm{M}\end{array}$ & $\begin{array}{l}50 \mathrm{~s} \\
50 \mathrm{~s}\end{array}$ & $\begin{array}{l}\text { Shop cashier } \\
\text { Lab technician }\end{array}$ & $\begin{array}{l}\text { India } \\
\text { India }\end{array}$ & $\begin{array}{l}\text { Hindu }(P) \\
\text { Hindu }(P)\end{array}$ & $\begin{array}{l}10 \\
10\end{array}$ \\
\hline $\begin{array}{l}\text { Naseem } \\
\text { Karim }\end{array}$ & London & $\begin{array}{l}\mathrm{F} \\
\mathrm{M}\end{array}$ & $\begin{array}{l}34 \\
44\end{array}$ & $\begin{array}{l}\text { Schoolteacher } \\
\text { Software } \\
\text { consultant }\end{array}$ & $\begin{array}{l}\text { London } \\
\text { India }\end{array}$ & $\begin{array}{l}\text { Muslim (P) } \\
\text { Muslim (P) }\end{array}$ & $\begin{array}{l}34 \\
32\end{array}$ \\
\hline Zain & London & M & 32 & $\begin{array}{l}\text { International } \\
\mathrm{NGO}\end{array}$ & Belfast & Muslim (P) & 14 \\
\hline Arjun & & M & 31 & Stockbroker & London & Hindu (NP) & 31 \\
\hline Saima & London & $\mathrm{F}$ & 26 & $\begin{array}{l}\text { Software } \\
\text { programmer }\end{array}$ & Belfast & Hindu (NP) & 4 \\
\hline
\end{tabular}

Key:

P - Practising

NP - Non-practising

\section{Biographical note}

Zahbia Yousuf is a PhD student at the Department of War Studies, Kings College London. Her research focuses on comparing the strategic conditions underlying the peace processes in Northern Ireland, Kashmir and Israel/Palestine. A D D R E S s: Department of War Studies, Kings College London, Strand, London WC2R 2LS, UK. [email: zahbia.yousuf@kcl.ac.uk] 